\title{
LEGAL STRUCTURE, FINANCIAL STRUCTURE, AND THE MONETARY POLICY TRANSMISSION MECHANISM
}

Stephen G. Cecchetti

\author{
Working Paper 7151 \\ http://www.nber.org/papers/w7151 \\ NATIONAL BUREAU OF ECONOMIC RESEARCH \\ 1050 Massachusetts Avenue \\ Cambridge, MA 02138 \\ June 1999
}

This paper was prepared for the conference "The Monetary Transmission Process: Recent Developments and Lessons for Europe," sponsored by the Deutsche Bundesbank in Frankfurt, Germany, on March 26-27, 1999, and is forthcoming in Deutsche Bundesbank, ed. The Monetary Transmission Process: Recent Developments and Lessons for Europe, Houndmills, Basingstoke, U.K.: Macmillan Publishing. I gratefully acknowledge comments from and discussions with Ignazio Angeloni, Paul Bennett, Stefan Gerlach, Heinz Hermann, Beverly Hirtle, James Kahn, Anil Kashyap, Kenneth Kuttner, Gabriel Perez Quiros, Margaret Mary McConnell, Robert Rich, and especially Paolo Pesenti. I thank Michael Ehrman for providing his programs, Rama Seth for helping with the data, and Valerie LaPorte for editorial assistance. All opinions expressed are those of the authors and not those of the National Bureau of Economic Research, the Federal Reserve Bank of New York, or of the Board of Governors of the Federal Reserve System.

(C) 1999 by Stephen G. Cecchetti. All rights reserved. Short sections of text, not to exceed two paragraphs, may be quoted without explicit permission provided that full credit, including (C) notice, is given to the source. 
Legal Structure, Financial Structure, and

the Monetary Policy Transmission Mechanism

Stephen G. Cecchetti

NBER Working Paper No. 7151

June 1999

JEL No. E5, G3

\begin{abstract}
Among the many challenges facing the new Eurosystem is the possibility that the regions of the euro area will respond differently to interest rate changes. In this essay, I provide evidence that differences in financial structure are the proximate cause for these national asymmetries in the monetary policy transmission mechanism, and that these differences in financial structure are a result of differences in legal structure. My conclusion is that unless legal structures are harmonized across Europe, the financial structures and monetary transmission mechanisms of the European union countries will remain diverse.
\end{abstract}

Stephen G. Cecchetti

Federal Reserve Bank of New York

New York, NY 10045

and NBER

Stephen.Cecchetti@ny.frb.org 


\section{Introduction}

Over the past decade the countries of central Europe have become more similar in many ways. As the new members of the European Monetary Union prepared for the birth of the euro on January 1, 1999, their economic policies became substantially more uniform. All eleven countries in the new euro area have virtually eliminated inflation and taken serious steps toward fiscal consolidation. ${ }^{1}$ As their monetary and fiscal policies have adjusted to meet these common goals, the countries' business cycle fluctuations appear to have become more synchronized as well. ${ }^{2}$ While this makes the job of the Eurosystem (the European Central Bank plus the central banks of the eleven monetary union member countries) easier, numerous difficult challenges remain. Primary among these is the making of policy in the face of the possibility that it will have differential impacts across the countries of the euro area.

The task facing the Eurosystem is even more difficult than that facing countries with stable monetary regimes, where the measurement of the national and regional impact of policy has already proved to be extremely difficult. The creation of the Eurosystem constitutes a regime shift in virtually every sense of the term. The introduction of the euro seems sure to prompt adjustments in the economies of the member countries, and these will probably alter the relationship between the actions of the central bank and the real economy. That is, the monetary transmission mechanism of the countries in the euro area will change, making the job of the new European Central Bank even more difficult than it is already. But how quickly will it change, and what will it become?

To answer this question, we must understand the fundamental determinants of the impact of policy actions on output and inflation. For insight into these determinants, I turn to the modern views of the monetary transmission mechanism, which assign a central role to financial structure. Kashyap and Stein (1997) provide a starting point; they focus on the importance of the banking system and go on to emphasize the distributional effects of monetary policy changes. The conventional wisdom has always been that some industries are more sensitive to interest rate changes than others, and so changes in

\footnotetext{
${ }^{1}$ Throughout the paper, I refer to the eleven countries of the Eurosystem, but provide information on only ten. Luxembourg is not included.

${ }^{2}$ See Angeloni and Dedola (1998).
} 
policy-controlled interest rates have differential effects across industries. The view based on financial structure both formalizes this reasoning and takes it one step further by noting that some firms are more dependent on banks for financing than others, and that this is true both across and within industries. According to this "lending view" of the transmission mechanism, monetary policy actions change the reserves available to the banking system, thereby affecting the willingness of banks to lend and, ultimately, the supply of loans. How this mechanism will affect individual firms depends on the financing methods available to them. Monetary policy has a bigger impact on firms that are reliant on banks for their financing. Furthermore, healthier banks will be able to adjust to the policy-induced reserve changes more easily than other banks will.

The distributional effects implied by the lending view of monetary policy transmission have clear implications for the euro area and the Eurosystem. Countries in which firms are more bank dependent and banking systems less healthy will be more sensitive to the Eurosystem's decisions to change interest rates. This brings me to the first question I will address in this paper: Is there evidence that the impact of monetary policy innovations varies across countries with the strength and scope of the banking system?

With this in mind, I examine differences in the size, concentration, and health of national banking systems, as well as in the availability of nonbank sources of finance. I find, consistent with the most casual observation, that banking system characteristics vary dramatically across the countries of the European Union (EU). Furthermore, these differences do seem to be related to estimated differences in the impact of interest rate changes on output and inflation. Countries with many small banks, less healthy banking systems, and poorer direct capital access display a greater sensitivity to policy changes than do countries with big healthy banks and deep, well-developed capital markets.

But this is just the first question. The more important issue facing the Eurosystem is whether the national banking systems, and the implied sensitivity of each country's real economy to monetary policy shocks, will change now that there is monetary union.

It is easy to assert that European banks will soon look like U.S. banks, exhibiting a financial structure and transmission mechanism similar to the American models. After all, the euro area does resemble the United States, at least superficially. It has a slightly larger population - 292 million for the eleven members of the monetary union relative 
to 270 million for the United States — and nearly as high a level of GDP — \$6.8 trillion compared with $\$ 8.1$ trillion in 1997 . The euro area also has a similar degree of openness to trade, with imports accounting for slightly more than 10 percent of GDP. These parallels, along with the fact that financial technology is easily transferable across national boundaries, have led a number of observers to conclude that the introduction of the euro may act as a catalyst, speeding the rate at which financial relationships in Europe become like those in the United States. For example, while Dornbusch, Favero, and Giavazzi (1998, pp. 48-49) do note the possibility for EU-wide asymmetries resulting from differences in financial structure, they assert that "the euro will change the way financial markets work, inducing corresponding changes in the monetary mechanism. In addition to pervasive deregulation already under way and innovation, the introduction of the euro will revolutionize the financial structure of Europe. Europe will in a short period become more nearly like the USA." McCauley and White (1997, p. 17) suggest that there may be an acceleration in the rate at which securities replace loans on the asset side of bank balance sheets and commercial paper replaces deposits on the liabilities side. They point to a "dramatic potential for assets to be stripped out of the banking system," and for securities markets to absorb as much as one-third of the corporate loans now originated in European banks. ${ }^{3}$ Overall, these commentators are speculating that the increased liquidity of European financial markets brought about by monetary union will lead to significant consolidation of banks, with mergers both nationally and internationally, as well as a direct substitution of traded equities and bonds for bank loans.

Why should we believe that the European financial structure will quickly be transformed into one that mirrors the one in the U.S. model? Without an explanation for the evolution of these countries' national financial structures that is based on their existing differences, such claims are unconvincing. What accounts for the variation in the financial intermediation systems across countries? Traditionally, we look to taxes and regulation for an explanation, and Dornbusch, Favero, and Giavazzi (1998) as well as White (1998)

\footnotetext{
${ }^{3}$ Similar points are made by White (1998), who suggests that competition in banking may be about to increase in Europe, stimulated by the introduction of the euro. In addition, a recent European Central Bank (1999) study suggests that European Monetary Union (EMU) may speed up the process of disintermediation and lead to a more geographically diversified and internationalized banking system.
} 
do mention these. Danthine, Giavazzi, Vives, and von Thadden (1999) identify a number of barriers to change, in national financial structure and note the importance of the historical path that has brought each country's banks to their current state. Danthine et al. (1999) go on to state that "legal differences between EU states, in particular the lack of some form of 'European corporate law,' also remain important and constitute an additional factor of market segmentation" (p. 45). Such disparities in legal structure can explain important economic patterns, and they can be maintained for long periods of time, significantly delaying the harmonization of national banking systems. ${ }^{4}$

It is my main contention that the differences in financial structure across the countries of Europe are a consequence of their dissimilar legal structures. My argument draws on the work of LaPorta, Lopez-de-Silanes, Shleifer, and Vishny (1997, 1998), who focus on the relationship between legal structures and finance. They argue that the structure of finance in a country depends on the rights accorded shareholders and creditors by the laws of that country, as well as on the degree to which these laws are enforced. The nature of the laws is, in turn, a product of the legal tradition on which the civil codes of a country are based. La Porta et al. establish that the character of a country's financial markets depends on its legal structure. Putting their arguments together with the lending view of the monetary transmission mechanism leads to the possibility that it is the legal system in a country that forms the basis for the structure of financial intermediation, and hence the impact of monetary policy on output and prices.

Table 1 reports the empirical findings that support the basic conclusion of the paper. After classifying countries by the "family" or origin of their legal structure, I calculate for each family the average level of an index of monetary policy's likely effectiveness (based on banking system size, concentration, and health, with a higher value implying a larger predicted impact) and the estimated impact of an interest rate change on output and

\footnotetext{
${ }^{4}$ For example, within the United States, more than 10 percent of firms with assets over $\$ 1$ million have chosen to incorporate in the state of Delaware, a state with less than $\frac{1}{2}$ of 1 percent of the country's population. Why is this? The answer is found by looking at the development of the legal structure in Delaware and how it differed from that in other states. Originally, large firms were incorporated in New Jersey because the state, in exchange for incorporation fees and franchise taxes, had liberalized its corporation law to allow various mergers and cross-holdings that were disallowed elsewhere. State law also gave very strong power to corporations' directors (Grandy 1989). Delaware copied New Jersey's statutes and then benefited from changes made to New Jersey's law by then Governor Woodrow Wilson in 1913. As this example suggests, the economic structure has its source in the legal structure.
} 
Table 1: Effectiveness of Policy and the Origins of the Legal System

\begin{tabular}{||l|c|c|c||}
\hline \hline & \multicolumn{2}{|c|}{ Index of Effectiveness } & \multicolumn{2}{|c||}{ Impact of Policy on } \\
Legal Family & of Monetary Policy & Output & Inflation \\
\hline \hline English & 1.1 & -0.45 & -0.21 \\
Scandinavian & 1.8 & -0.52 & -0.22 \\
French & 2.1 & -0.70 & -0.20 \\
German & 2.4 & -1.25 & -0.49 \\
\hline \hline
\end{tabular}

Note: The index of effectiveness of monetary policy, from Table 5 , is based on financial structure variables described in Section 3, with higher values implying a larger expected impact of interest rate changes on output and prices. The impact of policy on output and inflation, from Table 6 , is a measure of the maximum response, in percentage points, to an interest rate movement of 100 basis points, estimated using a small-scale structural model. Countries are classified by family or origin of their legal structure, and group means are reported based on data for Ireland, the United Kingdom, and the United States (English common law); Denmark and Sweden (Scandinavian common law); Belgium, France, Italy, Portugal, and Spain (French civil law); and Germany (German civil law).

inflation (from a small-scale structural model). The results suggest that a country's legal structure, financial structure, and monetary transmission mechanism are interconnected. The clear pattern is that the predicted effectiveness and its measured impact vary systematically based on the origin of a country's legal system. Countries with better legal protection for shareholders and debtors (English), have financial structures in which the lending channel of monetary transmission is expected to be less potent, and have a lower measured impact of an interest rate change on output and inflation.

The implication is that unless the laws governing shareholder and creditor rights and the enforcement of those laws are harmonized across the members of the European Monetary Union (EMU), monetary policy will continue to have a differential impact. Put slightly differently, it is my belief that the financial structures in the countries of the euro area will not converge into one large U.S.-style system unless there are dramatic legislative changes. If such legal harmonization occurs - that is, if the civil codes protecting shareholders and creditors are made uniform across the countries that have entered the monetary union - then the regional variation in the impact of interest rate changes on output and inflation should decrease. ${ }^{5}$ But if legal convergence does not occur, financial

\footnotetext{
${ }^{5}$ I should note that firms in countries that act slowly will be put at a competitive disadvantage, and so they might pressure their governments to speed up the legal changes. The potential strength of such regulatory competition is an open issue.
} 
structure will remain heterogeneous, and so will the monetary transmission mechanism, and the job of the Eurosystem will be to construct appropriate policy that takes these asymmetries into account. ${ }^{6}$

The remainder of this paper provides the building blocks for this argument. In Section 2, I provide a brief survey of the theories of the monetary transmission mechanism, focusing on the importance of financial structure to an understanding of monetary transmission. Section 3 assesses the national banking systems, including measures of overall size, concentration, health, and the relative importance of nonbank finance. Overall, this analysis allows me to evaluate the likely strength of the lending channel across countries. Section 4 reports estimates, for a set of ten countries, of the impact of an interest rate increase on output and inflation. These estimates follow the pattern that is expected. Countries where financial structure data suggest that the lending channel should be strong exhibit more sensitivity to monetary policy movements. In Section 5, I present the data and arguments from La Porta, Lopez-de-Silanes, Shleifer, and Vishny (1997, 1998) on the relationship between legal and financial structures. This allows me to test the prediction that countries with poor shareholder and creditor protections and poor law enforcement will have less developed financial systems and greater sensitivity of output and inflation to interest rate changes. While far from being definitive, the results are consistent with my main hypothesis: difference in legal systems give rise to variations in national financial structures, and these variations in turn lead to divergences in monetary transmission mechanisms. So long as the legal systems of the euro area countries remain distinct, the impact of interest rate changes across the euro area countries will differ.

\footnotetext{
${ }^{6}$ There is an alternative. A company may move to a country where the financial system better suits its needs. The La Porta et al. measures, reported in Table 7 below, suggest that the United Kingdom is the best country in the European Community in which to issue both bonds and stocks, and so firms that wish to have ready access to primary capital market financing may tend to concentrate there. But for this strategy to be successful, firms would have to both reincorporate and move assets into the alternative jurisdiction. The assets must move to provide the proper guarantees to investors. All of this seems unlikely.
} 


\section{Theories of the Transmission Mechanism}

A number of excellent and comprehensive surveys of the theories of the monetary transmission mechanism have appeared in recent years. These include Bernanke (1993), Gertler and Gilchrist (1993), Kashyap and Stein (1994, 1997), Hubbard (1995), and my own survey, Cecchetti (1995). As a result, I will be brief.

All theories of how interest rate changes affect the real economy share a common starting point. A monetary policy action begins with a change in the level of bank reserves. For this to have any real effects at all, there must be nominal rigidities in the economy. Otherwise, a change in the nominal quantity of outside money cannot have any impact on the real interest rate. While the ability of the central bank to change the level of bank reserves is not in question, the source of the nominal rigidity that allows the change in reserves to alter short-run real rates of return has been under debate for decades. The current state of this discussion is well summarized by Christiano, Eichenbaum, and Evans (1997). They distinguish three sets of theories: one set based on sticky wages, a second set based on sticky prices, and a third set built on the idea of limited participation. The sticky wage and sticky price models are the most familiar, and rest on the idea that there are costs to nominal price and wage changes, and so adjustments are infrequent. In limited participation models, introduced in Rotemberg (1984), individuals (households) are unable to adjust their cash balances sufficiently rapidly in response to changes in the environment - that is, households have a limited ability to participate in financial markets, and so must commit themselves to certain portfolio holdings for relatively long periods of time. ${ }^{7}$

\footnotetext{
${ }^{7}$ In addition to the differences in the type of nominal rigidity, there are variations in the way in which the rigidites are modeled. These variations are more than formal; they have very different implications for the dynamic effects of nominal shocks on real variables. Different modeling strategies as based on differences in the timing of price or wage change decisions. There are three basic schemes used, based on Fischer (1977), Taylor (1980), and Calvo (1983), and they create very different dynamic responses of real variables to nominal shocks. Fischer, for example, assumes prices are predetermined, meaning that at some time agents set prices for some number of future periods; the level of prices set on the decision date can differ for the different periods before the next decision date. In this model, the impact of a nominal shock lasts for only as long as it takes for all price setters to have a chance to reset their price schedules. In the Taylor model, prices or wages are assumed to be fixed, meaning that their nominal value does not vary between decision dates. When prices or wages are fixed, nominal shocks die out only asymptotically. In Calvo's model, price setters change their prices according to a poison process, leading to a variety of possible dynamics.
} 
The sources of nominal rigidities are relatively unimportant for the discussion of the mechanism by which interest rate changes have short-run effects on output and prices, and so I will move directly to a discussion of the current theories of the transmission mechanism. ${ }^{8}$ Our current views are based on the work of Bernanke (1983), Bernanke and Blinder (1992), and Bernanke and Gertler (1989, 1990). These authors distinguish between the traditional money view, in which interest rate movements affect the level of investment and exchange rates directly, and the lending view, in which financial intermediaries play a prominent role in transmitting monetary impulses to output and prices. I will describe each of these in turn.

The traditional view, which is largely the foundation for the textbook IS-LM model, is based on the notion that reductions in the quantity of outside money raise real rates of return. This outcome has two effects, the first directly from interest rates to investment and the second through exchange rates. An interest rate increase reduces investment, as there are fewer profitable projects available at higher required rates of return. A policy action induces a movement along a fixed marginal-efficiency-of-investment schedule. This interest rate channel will be more powerful the less substitutable outside money is for other assets. The exchange rate channel is also familiar from textbook models. Here, an interest rate increase results in a real appreciation of the domestic currency, reducing the foreign demand for domestically produced goods. Regardless of whether the transmission mechanism occurs through the interest rate or the exchange rate, there is no real need to discuss banks. In fact, there is no reason to distinguish any of the "other" assets in investors' portfolios. This is a simple two-asset model.

An important implication of this traditional model of the transmission mechanism concerns the incidence of the investment decline. Since there are no externalities or market imperfections, only the least socially productive projects, those with the lowest

\footnotetext{
${ }^{8}$ Longer run considerations, such as the potential costs or benefits of modest levels of inflation, critically depend on understanding the sources of nominal rigidity. For example, Akerlof, Dickens, and Perry (1996) and Groshen and Schweitzer (1997) consider whether small positive levels of aggregate inflation can facilitate real adjustments in the presence of an aversion to nominal wage declines, suggesting that the long-run goal for inflation might be positive. But Feldstein (1996) contends that the tax distortions created by inflation reduce the level of output permanently, an argument that suggests that the optimal level of inflation may even be negative. Overall, most economists now seem to agree that inflation leads to lower levels of real output and may even retard long-run growth. See Feldstein (1999) for a summary.
} 
rates of return, go unfunded. As a result, the capital stock is marginally lower, but, given that a decline is going to occur, the allocation of the decline across sectors is socially efficient.

As most of the surveys cited earlier emphasize, the lending view has two parts, one that focuses on the impact of policy changes on borrower balance sheets and a second that focuses on bank loans. In both, the effectiveness of policy depends on capital market imperfections that make it easier for some firms to obtain financing than others. Information asymmetries and moral hazard problems, together with bankruptcy laws, mean that the state of a firm's balance sheet has implications for its ability to obtain external finance. ${ }^{9}$ By reducing expected future sales and by increasing the cost of rolling over a given level of nominal debt, policy-induced increases in interest rates (which are both real and nominal) cause a deterioration in the firm's net worth. Furthermore, there is an asymmetry of information in that borrowers (firms) have better information about the potential profitability of investment projects than creditors (banks). As a result, as the firm's net worth declines, the firm becomes less creditworthy because it has an increased incentive to misrepresent the riskiness of potential projects - an outcome that will lead potential lenders to increase the risk premium they require when making a loan. The asymmetry of information makes internal finance of new investment projects cheaper than external finance.

More important for the transmission mechanism per se is that some firms are dependent on banks for finance, and that monetary policy affects bank loan supply. A reduction in the quantity of reserves forces a reduction in the level of deposits, which must be matched by a fall in loans. Nevertheless, lower levels of bank loans will have an impact on the real economy only insofar as there are firms without an alternative source of investment funds.

Substantial empirical evidence supports the importance of both capital market imperfections and firm dependence on bank financing. Kashyap and Stein (1997) provide a summary of two types of studies. The first type suggests that banks rely to a substantial extent on reservable-deposit financing and that, for this reason, a contraction in reserves will prompt banks to contract their balance sheets, reducing the supply of loans. The

\footnotetext{
${ }^{9}$ As emphasized by Kashyap and Stein (1994), this is true for both financial and nonfinancial firms.
} 
second type establishes that there are a significant number of bank-dependent firms that are unable to mitigate the shortfall in bank lending with other sources of finance. Overall, recent research does imply the existence of a lending channel. ${ }^{10}$

Models of monetary policy transmission based on financial structure suggest a natural place to begin looking for sources of cross-country differences in the monetary transmission mechanism. The prediction is that overall, the transmission mechanism will be stronger in those countries where firms are more bank dependent, and where the banking system is less healthy and less concentrated. In the first instance, firms have less direct access to capital markets are unable to blunt the effect of a contraction in bank loans. In the second, banks themselves have restricted access to nonreservable deposits and are forced to contract their balance sheets by more for a given change in policy. In the next section of the paper, I examine data on national financial structure and try to rank countries based on the likely strength of the transmission mechanism. To the extent that these cross-country differences are present, then the lending view implies that they will persist until the financial structures become more uniform. ${ }^{11}$

\section{Likely Strength of the Transmission Mechanism}

In assessing the likely impact of an interest rate change on output and prices in the various countries of the EMU, I follow the recent work of Kashyap and Stein (1997) and assemble data on the size and concentration of the banking systems, along with measures of banking system health, the importance of bank financing, and the size of firms. The indicators are chosen to conform as closely as possible to the economic quantities that the lending view suggests should be important. The balance sheets of large, healthy banks are not as sensitive to policy, because reserve contractions can be readily offset with alternative forms of finance that do not attract reserve requirements. In addition, I examine measures of the development of equity and debt markets in the EMU countries.

\footnotetext{
${ }^{10}$ This is not to say that the traditional mechanisms, through interest rates and exchange rates, are not present as well. Unfortunately, it has proved to be very difficult to disentangle the individual importance of the various channels of transmission.

${ }^{11}$ It is important to note that there can be significant cyclical and secular changes in the strength of the lending channel as the health and concentration of the banking system change, and as capital markets become deeper and broader.
} 
Table 2: Size and Concentration of Banking Industry by Country, 1996

\begin{tabular}{||l|c|c|c||}
\hline \hline Country & $\begin{array}{c}\text { Number of } \\
\text { Credit } \\
\text { People }\end{array}$ & $\begin{array}{c}\text { Banks } \\
\text { per Million } \\
\text { Top Five Banks }\end{array}$ & Concentration Ratios: \\
\hline Monetary Union Members \\
\hline Austria & 1019 & 126 & 48 \\
Belgium & 140 & 14 & 57 \\
Finland & 350 & 68 & 78 \\
France & 1373 & 24 & 40 \\
Germany & 3517 & 43 & 17 \\
Ireland & 62 & 18 & 41 \\
Italy & 937 & 16 & 25 \\
Netherlands & 172 & 11 & 79 \\
Portugal & 51 & 5 & 46 \\
Spain & 313 & 8 & 17 \\
\hline Members of the EU Not in EMU & 117 & 22 & 71 \\
\hline Denmark & 20 & 2 & 90 \\
Greece & 124 & 14 & 28 \\
Sweden & 878 & 8 & 30 \\
United Kingdom & 478 & 17 \\
\hline \hline Other Countries & \multicolumn{3}{|l||}{} \\
Japan United States & 10803 & 40 & 49 \\
\hline \hline
\end{tabular}

Note: Concentration ratios are calculated as the percentage of each country's bank assets accounted for by the largest five banks. Source: See the Data Appendix.

Firms with ready capital market access, which are more likely to be found in countries with extensive secondary securities markets, will be better insulated from bank loansupply contractions. Combining these measures, I construct an index of the probable strength of the monetary transmission mechanism. ${ }^{12}$

To assess the importance of small banks in a country's financial system, Table 2 reports the number of banks, the number of banks per million population, and measures of concentration for all of the EU countries plus Japan and the United States. ${ }^{13}$ The data

\footnotetext{
${ }^{12}$ After I collected the data for this section, the European Central Bank issued its report Possible Effects of EMU on the EU Banking Systems in the Medium and Long Term. The appendix tables in that report contain much of the same information presented here.

${ }^{13}$ Throughout the analysis, I omit Luxembourg.
} 
reveal that Austria and Finland have many more banks per capita - 126 and 68 per million people, respectively — than any of the other countries. The remaining countries fall into roughly three groups: the United Kingdom, Japan and the southern European countries of Spain, Portugal, and Greece have less than 10 banks per million; Germany and the United States have slightly more than 40; and the remaining countries have between 13 and 25 .

Turning to the concentration measures in the fourth column of the table, it is interesting to note that countries with more banks do not necessarily have less concentrated banking systems. France, for example, with 1373 banks and just under 60 million people, has a fairly high concentration ratio: the top five French banks account for nearly one-half of total banking system assets and the top ten for nearly two-thirds. Overall, Denmark, Germany, and the United Kingdom have the least concentrated banking systems in Europe. By comparison, large banks clearly dominate Sweden, Finland, Belgium, the Netherlands, and Greece. The remaining countries are somewhere in between.

What do these findings imply for the strength of the transmission mechanisms in the countries examined? Austria, Germany, and the United States have systems composed of a network of small banks, and so one would expect the lending channel to be relatively strong in those countries. At the other end of the spectrum, Belgium, Finland, Ireland, the Netherlands, Portugal, Sweden, and the United Kingdom all have banking industries dominated by a small number of relatively large banks, with a modest periphery of small institutions. The remaining countries - Denmark, France, Greece, Italy, and Japan fall in a middle group.

The healthier a nation's banking system, the stronger the expected impact of policy movements. With this in mind, I have collected a set of standard gauges of banking system health, including the return on assets, loan loss provisions, net interest margin, and operating costs, and I have calculated a summary rating of overall system soundness. Focusing primarily on the return on assets and the Thomson ratings in Table 3 leads to the following rankings: Ireland, the United Kingdom and the United States have the healthiest banks; Austria, Belgium, Germany, Netherlands, Spain, Denmark and Greece are second; Finland, France, Italy, Portugal and Sweden are third; and Japan is alone at the bottom. 
Table 3: Measures of Banking Industry Health, by Country - 1996

\begin{tabular}{|c|c|c|c|c|c|}
\hline Country & $\begin{array}{c}\text { Return } \\
\text { on Assets }\end{array}$ & $\begin{array}{l}\text { Loan Loss } \\
\text { Provisions }\end{array}$ & $\begin{array}{l}\text { Net Interest } \\
\text { Margin }\end{array}$ & $\begin{array}{c}\text { Operating } \\
\text { Costs }\end{array}$ & $\begin{array}{c}\text { Average } \\
\text { Thomson Rating }\end{array}$ \\
\hline \multicolumn{6}{|c|}{ Monetary Union Members } \\
\hline Austria & 0.38 & 0.59 & 1.67 & 2.45 & $2.38(4)$ \\
\hline Belgium & 0.52 & 0.17 & 1.41 & 1.67 & $2.00(6)$ \\
\hline Finland & 0.50 & 0.78 & 2.07 & 3.05 & $2.83(3)$ \\
\hline France & 0.36 & 0.24 & 1.43 & 1.84 & $2.28(16)$ \\
\hline Germany & 0.44 & 0.18 & 1.24 & 2.19 & $1.97(19)$ \\
\hline Ireland & 1.57 & 0.17 & 3.36 & 3.32 & $1.83(3)$ \\
\hline Italy & 0.33 & 0.62 & 2.32 & 3.19 & $2.57(15)$ \\
\hline Netherlands & 0.75 & 0.26 & 2.06 & 2.48 & $2.10(5)$ \\
\hline Portugal & 0.91 & 0.42 & 2.60 & 3.80 & $2.30(5)$ \\
\hline Spain & 0.76 & 0.32 & 2.20 & 2.69 & $1.79(11)$ \\
\hline \multicolumn{6}{|c|}{ Members of the EU Not in EMU } \\
\hline$\overline{\text { Denmark }}$ & 0.91 & 0.11 & 1.28 & 0.97 & $2.33(3)$ \\
\hline Greece & 1.11 & 0.18 & 1.98 & 2.77 & $2.50(6)$ \\
\hline Sweden & 1.28 & 0.25 & 1.90 & 1.77 & $2.50(5)$ \\
\hline United Kingdom & 1.28 & 0.18 & 2.15 & 2.42 & $2.04(23)$ \\
\hline \multicolumn{6}{|l|}{ Other Countries } \\
\hline Japan & 0.01 & 0.75 & 1.17 & 1.03 & $3.32(44)$ \\
\hline United States & 1.42 & 0.10 & 2.68 & 3.51 & $1.73(344)$ \\
\hline
\end{tabular}

Notes: Except for the Thomson ratings, all figures in the table are calculated as a percentage of total bank assets. The numbers in parentheses in column 5 are the number of banks rated by Thomson in each country, and used to compute the average. See the Data Appendix. 
Table 4: Importance of External and Bank Finance by Country, 1996

\begin{tabular}{|c|c|c|c|c|c|}
\hline Country & $\begin{array}{c}\text { Number of } \\
\text { Publicly } \\
\text { Traded } \\
\text { Firms }\end{array}$ & $\begin{array}{c}\text { Publicly } \\
\text { Traded } \\
\text { Firms } \\
\text { per Capita }\end{array}$ & $\begin{array}{c}\text { Ratio of } \\
\text { Market } \\
\text { Capitalization } \\
\text { to GDP } \\
\text { (Percent) } \\
\end{array}$ & $\begin{array}{c}\text { Ratio of } \\
\text { Corporate } \\
\text { Debt } \\
\text { to GDP } \\
\text { (Percent) } \\
\end{array}$ & $\begin{array}{c}\text { Ratio of } \\
\text { Bank Loans } \\
\text { to All Forms } \\
\text { of Finance } \\
\text { (Percent) } \\
\end{array}$ \\
\hline \multicolumn{6}{|c|}{ Monetary Union Members } \\
\hline Austria & 106 & 13.15 & 15 & 46 & 65 \\
\hline Belgium & 139 & 13.68 & 45 & 60 & 49 \\
\hline Finland & 71 & 13.87 & 50 & 34 & 39 \\
\hline France & 686 & 11.75 & 38 & 49 & 49 \\
\hline Germany & 681 & 8.32 & 29 & 58 & 55 \\
\hline Ireland & 76 & 21.59 & 18 & 13 & 80 \\
\hline Italy & 217 & 3.78 & 21 & 37 & 50 \\
\hline Netherlands & 217 & 13.97 & 96 & 48 & 53 \\
\hline Portugal & 158 & 16.11 & 23 & 19 & 62 \\
\hline Spain & 357 & 9.09 & 42 & 11 & 58 \\
\hline \multicolumn{6}{|c|}{ Members of the EU Not in EMU } \\
\hline$\overline{\text { Denmark }}$ & 237 & 45.06 & 41 & 105 & 25 \\
\hline Greece & 245 & 23.44 & 20 & 3 & 48 \\
\hline Sweden & 229 & 25.90 & 99 & 73 & 32 \\
\hline United Kingdom & 2433 & 41.39 & 150 & 45 & 37 \\
\hline \multicolumn{6}{|l|}{ Other Countries } \\
\hline Japan & 2334 & 18.56 & 67 & 39 & 59 \\
\hline United States & 8479 & 31.94 & 111 & 64 & 21 \\
\hline
\end{tabular}

Notes: Market capitalization is the year end value of firms listed on major exchanges. For the U.S., 3 exchanges are used, for Japan, there are 8, and for the remainder of the countries one. See the Data Appendix. 
Finally, I turn to the availability of nonbank finance for firms in the EU and other countries. The relevant data are reported in Table 4. Following Kashyap and Stein (1997) and La Porta, Lopez-de-Silanes, Shleifer, and Vishny (1997), I examine the number of publicly listed firms, the extent of secondary equity and debt markets, and the ratio of bank loans to all forms of finance. While these are crude measures of access to external finance, they are informative. As in the case of Table 2, the countries can be divided into three groups. Austria, Ireland, Italy, Portugal, and Greece appear to have the least well developed external capital markets. They have small equity and bond markets, and bank loans account for a high percentage of firm financing. By contrast, Belgium, Denmark, Sweden, the United Kingdom, and the United States all have substantial secondary capital markets, and banks are a less important source of finance. The remaining six countries are somewhere in between these two groups.

Table 5 summarizes the material in Tables $2-4$ and suggests the overall relative strength of monetary policy in the fourteen EU countries, Japan, and the United States. The final column, labeled "Overall Strength of Monetary Policy" is a measure of the predicted effectiveness of monetary policy on output and inflation, where higher values suggest a stronger lending channel and therefore a larger impact. Overall, the pattern is very similar to the one reported in Kashyap and Stein's (1997) Table 6. Most important, the predicted effects of interest rate movements vary greatly across countries. For example, looking at the EMU countries, one would expect that a given interest rate change would have the most impact in Austria and Italy, countries in which small banks are relatively important, the banking systems are less healthy, and firms have little access to nonbank sources of finance. The opposite is true of Belgium, Ireland, and the Netherlands, where the banking systems are large and healthy and nonbank finance is readily available; in these countries, interest rate movements would be expected to have a more muted impact. ${ }^{14}$

The conclusions of this section could be criticized as applying only to the pre-EMU

\footnotetext{
${ }^{14} \mathrm{~A}$ significant failing of this analysis is the assumption that these relative rankings are not changing over time. Surely, if I had chosen different dates to measure the relative health and concentration of the banking system, I would have created a different set of rankings for the first two indicators. It is entirely possible that both the relative importance of small banks and the health of the banking system will become increasingly uniform across countries, leaving only differences in external finance.
} 
Table 5: Summary of Factors Affecting the Strength of the Monetary Transmission Mechanism

\begin{tabular}{|c|c|c|c|c|}
\hline Country & $\begin{array}{c}\text { Importance } \\
\text { of Small Banks } \\
\text { (1) }\end{array}$ & $\begin{array}{c}\text { Bank Health } \\
\text { (2) }\end{array}$ & $\begin{array}{c}\text { Availability of } \\
\text { Alternative Finance } \\
\text { (3) }\end{array}$ & $\begin{array}{c}\text { Overall } \\
\text { Impact of } \\
\text { Monetary Policy } \\
\text { (4) }\end{array}$ \\
\hline \multicolumn{5}{|c|}{ Monetary Union Members } \\
\hline Austria & 3 & 2 & 3 & 2.67 \\
\hline Belgium & 1 & 2 & 1 & 1.33 \\
\hline Finland & 1 & 3 & 2 & 2.00 \\
\hline France & 2 & 3 & 2 & 2.33 \\
\hline Germany & 3 & 2 & 2 & 2.33 \\
\hline Ireland & 1 & 1 & 3 & 1.67 \\
\hline Italy & 2 & 3 & 3 & 2.67 \\
\hline Netherlands & 1 & 2 & 2 & 1.67 \\
\hline Portugal & 1 & 3 & 3 & 2.33 \\
\hline Spain & 2 & 2 & 2 & 2.00 \\
\hline \multicolumn{5}{|c|}{ Members of the EU not in EMU } \\
\hline Denmark & 2 & 2 & 1 & 1.67 \\
\hline Greece & 2 & 2 & 3 & 2.33 \\
\hline Sweden & 1 & 3 & 1 & 1.67 \\
\hline United Kingdom & 1 & 1 & 1 & 1.00 \\
\hline \multicolumn{5}{|l|}{ Other Countries } \\
\hline Japan & 2 & 4 & 2 & 2.67 \\
\hline United States & 3 & 1 & 1 & 1.67 \\
\hline
\end{tabular}

Notes: Column 1 is based on Table 2, column 2 on Table 3 and Column 3 on Table 4 . Column 4 is an average of Columns 1, 2, and 3. 
period. But will the introduction of the euro be a catalyst for the harmonization of financial structure across the EMU? I take this question up in more detail later, but at this point I will simply mention that the recent European Central Bank (1999) report "Possible Effects of EMU on the EU Banking Systems in the Medium to Long Run" provides very little evidence to suggest that an increase in either international banking competition or securitization and disintermediation will occur quickly.

\section{Measuring the Impact of Policy on Output and Prices}

Testing the proposition that the banking system's concentration, health, and importance have a material impact on the monetary transmission mechanism requires an estimate of the effects of an interest rate change on output and prices. Numerous studies report such estimates for some or all of the countries of the EU. These include Gerlach and Smets (1995), who estimate a three-variable structural vector autoregression based on long-run restrictions; de Bondt (1997), who presents estimates of the impact of policy on output and prices for Germany, France, Italy, United Kingdom, Belgium and Netherlands that are based on the work of other authors; Dornbusch, Favero, and Giavazzi (1998), who report estimates of the impact of policy on output and prices derived from both small vector-autoregressive models and large structural models, for Italy, Germany, France, Spain, Sweden, and the United Kingdom; Keiler and Saarenheimo (1998), who study France, Germany and the United Kingdom, concluding that the transmission mechanism is not significantly different across the three countries; and Vlaar and Schuberth (1998), who examine money demand functions for fourteen EU countries; Ehrmann (1998), who estimates structural vector autoregressions for thirteen countries and finds considerable differences in the intensity of the response of output and prices to monetary shocks across countries; and Cecchetti and Rich (1999), who look at a simple two-variable system for Australia, Canada, France, Italy, Switzerland, the United Kingdom, and the United States and find large differences in the implied impacts.

Each of these studies has advantages and disadvantages. Overall, I have chosen to examine the results reported by Ehrmann (1998). The appeal of Ehrmann's approach 
is that it yields a series of estimates, all based on the same methodology, for nearly the full set of EU countries. Ehrmann uses techniques devised by King, Plosser, Stock, and Watson (1991). In effect, he identifies monetary shocks using a combination of long-run and short-run restrictions. The methods are described both in his paper and in Cecchetti, McConnell, and Perez Quiros (1999). For each country, the model has either four or five variables, including output, inflation, and an interest rate, and, with the exception of Germany, an exchange rate. When a fifth variable is present, it is either a second interest rate or a commodity price index. ${ }^{15}$

Figure 1 plots the responses of output and inflation to a 100 basis point interest rate movement for ten EU countries and the United States. ${ }^{16}$ These ten countries are the ones for which Ehrmann is able to generate consistent and plausible results. ${ }^{17}$ As is clear from these plots, the point estimates of the impulse response functions vary dramatically across countries. Looking at the impact of interest rate movements on output, note that for France and Germany, the peak impact is nearly twice what it is in the remaining European countries, and fifteen times the estimated impact in the United States. The impact of policy on inflation also varies substantially.

Table 6 reports the maximum impact of a 100 basis point monetary contraction on output and inflation for all of the countries for which I have estimates. I also include a measure of the timing of the impact - the quarter at which the maximum effect occurs. The final column in the table presents a measure of the ratio of the average output response to the average inflation response. This measure is related to the sacrifice ratio because it is roughly the output loss for a 1-percentage-point decline in inflation over a horizon of approximately three years. Unfortunately, these estimates are not terribly precise, a point that is clear from the results in Ehrmann's paper, ${ }^{18}$ and so we should not take some of the numbers too seriously.

\footnotetext{
${ }^{15}$ See Appendix A in Ehrmann (1998) for additional details.

${ }^{16}$ The results for the United States are derived from Cecchetti (1996).

${ }^{17}$ Although he reports estimates for thirteen countries, the estimates for three of these countries appear to be difficult to interpret. In the case of Finland, for example, the impact of monetary tightening is to increase output, not decrease it. For Austria and the Netherlands, we have not been able to replicate the results in the current version of Ehrmann's paper.

${ }^{18}$ Figures 1- 13 in Ehrmann (1998) show that the impulse response functions are rarely significantly different from zero. The same point is made in Cecchetti (1998) and Cecchetti and Rich (1999).
} 
Figure 1: Reaction of Output and Inflation to a 100 Basis Point Increase in Interest Rates Quarterly by Country, in Percent
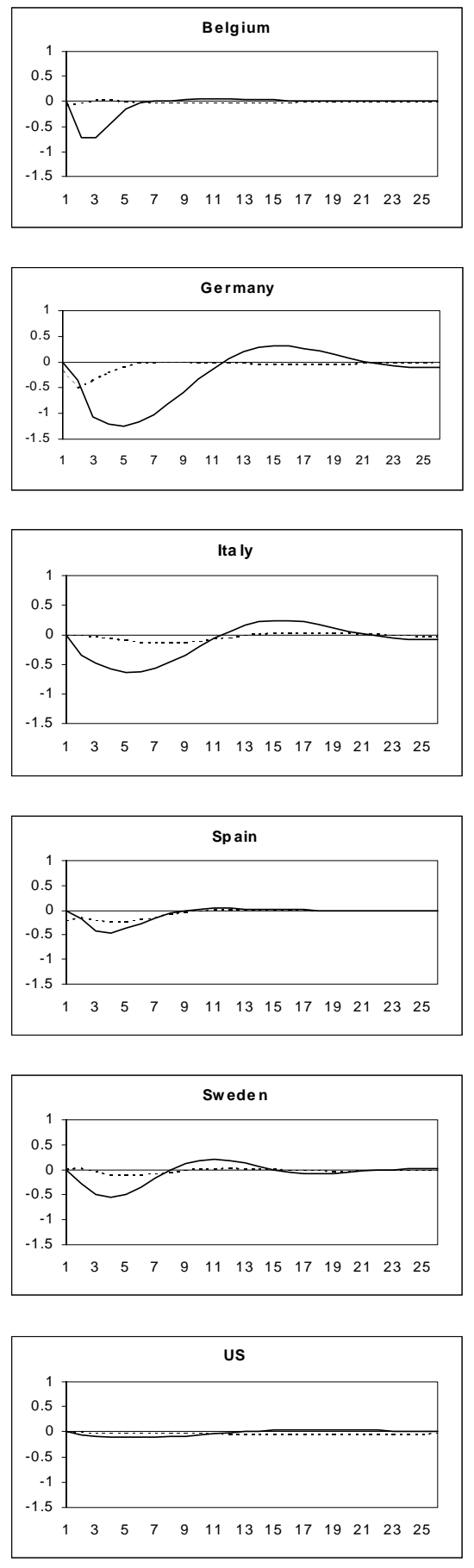
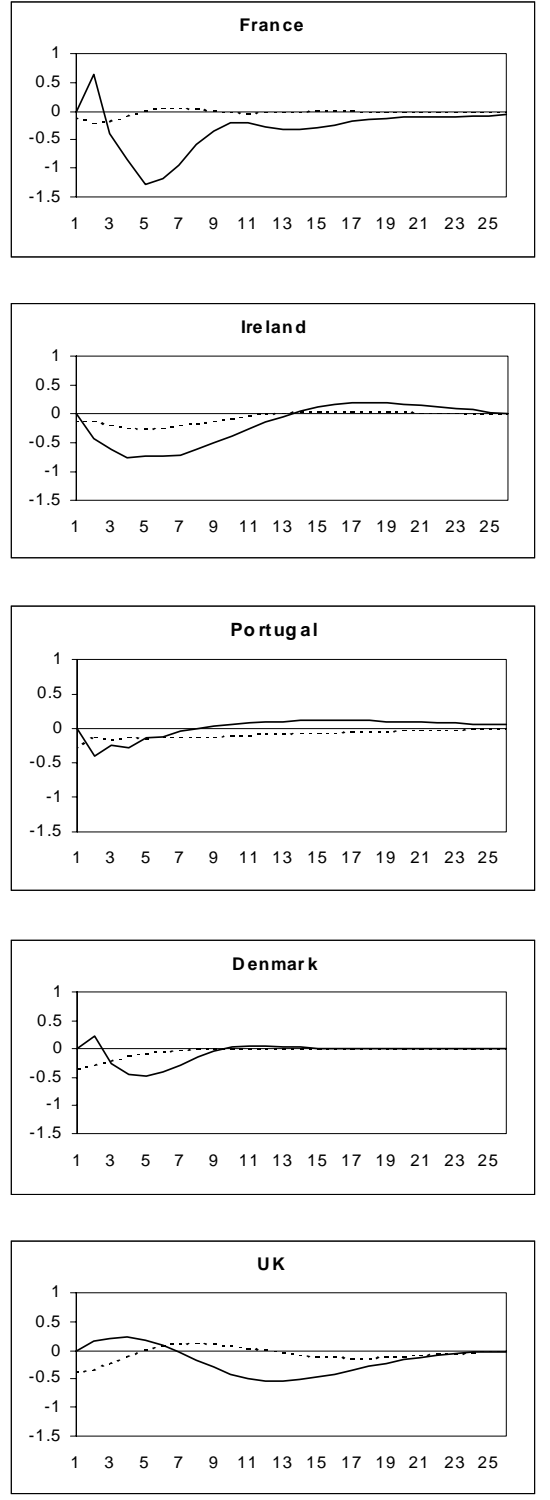

Solid Line: Output Response Dotted Line: Inflation Response 
Table 6: Impact of Interest Rate Movements on Output and Inflation

\begin{tabular}{|c|c|c|c|c|c|}
\hline \multirow[b]{2}{*}{ Country } & \multicolumn{2}{|c|}{ Output } & \multicolumn{2}{|c|}{ Inflation } & \multirow[b]{2}{*}{$\begin{array}{c}\text { Approximate } \\
\text { Sacrifice Ratio }\end{array}$} \\
\hline & $\begin{array}{l}\text { Maximum } \\
\text { Impact }\end{array}$ & $\begin{array}{c}\text { Quarter of } \\
\text { Maximum } \\
\text { Impact }\end{array}$ & $\begin{array}{l}\text { Maximum } \\
\text { Impact }\end{array}$ & $\begin{array}{c}\text { Quarter of } \\
\text { Maximum } \\
\text { Impact }\end{array}$ & \\
\hline \multicolumn{6}{|c|}{ Monetary Union Members } \\
\hline Austria & - & - & - & - & - \\
\hline Belgium & -0.72 & 2 & -0.05 & 1 & -45.29 \\
\hline Finland & - & - & - & - & - \\
\hline France & -1.30 & 5 & -0.21 & 2 & -12.07 \\
\hline Germany & -1.21 & 5 & -0.48 & 2 & -5.83 \\
\hline Ireland & -0.76 & 4 & -0.25 & 5 & -3.45 \\
\hline Italy & -0.64 & 5 & -0.25 & 9 & -5.01 \\
\hline Netherlands & - & - & - & - & - \\
\hline Portugal & -0.39 & 2 & -0.28 & 1 & -0.58 \\
\hline Spain & -0.46 & 4 & -0.23 & 4 & -1.34 \\
\hline \multicolumn{6}{|c|}{ Members of the EU Not in EMU } \\
\hline Denmark & -0.48 & 5 & -0.34 & 1 & -1.69 \\
\hline Greece & - & - & - & - & - \\
\hline Sweden & -0.56 & 4 & -0.11 & 5 & -5.61 \\
\hline United Kingdom & -0.53 & 13 & -0.37 & 1 & -2.57 \\
\hline \multicolumn{6}{|l|}{ Other Countries } \\
\hline$\overline{\text { Japan }}$ & - & - & - & - & - \\
\hline United States & -0.07 & 6 & -0.017 & 12 & -3.27 \\
\hline
\end{tabular}

Sources: Estimates for the United States are from Cecchetti (1996); those for the remaining countries are from the estimation of Ehrmann's model in Cecchetti, McConnell, and Perez Quiros (1999). 


\section{Systematic Differences in National Legal Systems}

If it is the differences in financial systems that are creating the cross-sectional variation in the transmission mechanism, it is natural to look for the causes of these differences. As noted earlier, La Porta, Lopez-de-Silanes, Shleifer, and Vishny $(1997,1998)$ have examined the relationship between a country's legal system and its financial system. The premise of their work is that investors provide capital to firms only if the investors have the ability to get their money back. For equity holders, this means that they must be able to vote out directors and managers who do not pay them. For creditors, this means that they must have the authority to repossess collateral. In addition to having nominal legal rights, these groups must also have confidence that the laws will be enforced.

La Porta et al. $(1997,1998)$ collect data on the legal systems in forty-nine countries. They show that all of the legal systems in these countries belong to one of four families: English common law, French civil law, Scandinavian civil law, and German civil law. With regard to shareholder rights - specifically, the ability of shareholders to vote directors out — English-common-law-countries have the best protections and Frenchcivil-law countries have the worst. The pattern is similar for creditor rights, which entail the right to reorganize or liquidate a firm. The pattern for enforcement is a bit different: Scandinavian-civil-law countries have the most rigorous law enforcement, while Frenchcivil-law countries have the most lax.

Table 7 reproduces a portion of Table II from La Porta et al. (1997). The column labeled "Shareholder Rights" reports an index that is higher when shareholders find it less costly and difficult to vote directors out. The column labeled "Creditor Rights" reports an analogous index that is lower when creditors experience less difficulty gaining

possession of property that has been used to collateralize a bond or loan. Enforcement is an assessment of countries' rigor in carrying out their laws, with a higher score implying more aggressive enforcement. Finally, the table reports the legal family from which each country's laws are derived.

Using these data to examine the relationship between shareholder rights, creditor rights, and enforcement on the one hand, and the concentration of ownership and the availability of external finance on the other, La Porta et al. (1997, 1998) come to two con- 
Table 7: Shareholder Rights, Creditor Rights, and Enforcement, by Country

\begin{tabular}{||l|c|c|c|c||}
\hline \hline Country & $\begin{array}{c}\text { Shareholder } \\
\text { Rights }\end{array}$ & $\begin{array}{c}\text { Creditor } \\
\text { Rights }\end{array}$ & Enforcement & $\begin{array}{c}\text { Origin of } \\
\text { Legal System }\end{array}$ \\
\hline Monetary Union Members \\
\hline Austria & 2 & 3 & 10.00 & German \\
Belgium & 0 & 2 & 10.00 & French \\
Finland & 2 & 1 & 10.00 & Scandinavian \\
France & 2 & 0 & 8.98 & French \\
Germany & 1 & 3 & 9.23 & German \\
Ireland & 3 & 1 & 7.80 & English \\
Italy & 0 & 2 & 8.33 & French \\
Netherlands & 2 & 2 & 10.00 & French \\
Portugal & 2 & 1 & 8.68 & French \\
Spain & 2 & 2 & 7.80 & French \\
\hline Members of the EU Not in EMUU & 3 & 3 & 10.00 & Scandinavian \\
Denmark & 1 & 1 & 6.18 & French \\
Greece & 2 & 2 & 10.00 & Scandinavian \\
Sweden & 4 & 4 & 8.57 & English \\
\hline United Kingdom & 3 & 2 & 8.98 & German \\
\hline Other Countries & Japan \\
United States & 5 & 1 & 10.00 & English \\
\hline \hline
\end{tabular}

Source: La Porta et al. (1997), Table II. 
clusions. First, corporate ownership is more concentrated in countries where shareholders and creditors are poorly protected by both the substance of the law and its enforcement. Second, and more germane to the current discussion, countries with weaker legal rules and less rigorous law enforcement have smaller and narrower capital markets. Overall, English-common-law countries have the least concentration of corporate ownership and the largest and deepest capital markets. French-civil-law countries have the most concentrated ownership and the smallest capital markets. La Porta et al. (1997) conclude that the "differences in the nature and effectiveness of the financial systems around the world can be traced, in part, to differences in investor protection against expropriation by insiders, as reflected by legal rules and the quality of their enforcement" (p. 1131). Their findings are confirmed by the data in Table 4, which show clearly that the United States and the United Kingdom have much more extensive capital markets than France and Italy.

\section{The Relationship of the Legal Environment to the Impact Policy}

Following the demonstration in La Porta et al. $(1997,1998)$ that the systematic variation in systems of corporate governance and finance across countries can be tied to the differences in their legal systems, I ask if the variation in the predicted strength of the lending channel and the estimated impact of interest rate movements on output and inflation can be traced to these same legal differences. ${ }^{19}$ To address this question, I combine the data from Table 5 on the predicted strength of the lending channel of monetary transmission and from Table 6 on the size of the impact of interest rate movements on output and inflation with the measures of cross-country differences in legal organization from Table 7. I report the results of two straightforward exercises. The first separates the countries by the origin of their legal system and constructs group averages for the

\footnotetext{
${ }^{19}$ White (1998) makes a related point when he notes that the legal, tax, regulatory, and supervisory frameworks within which financial institutions operate differ significantly across the various countries of the EU. All of these differences make direct competition more complex and less appealing. He goes on to focus on differences in the EU countries' labor laws and regulatory restrictions on the types of financial products that can be offered. These effects are surely complementary to the ones I address here.
} 
Table 8: Effectiveness of Policy and the Origin of the Legal System

\begin{tabular}{|c|c|c|c|c|}
\hline Legal Family & $\begin{array}{c}\text { Predicted Effectiveness } \\
\text { of Monetary Policy }\end{array}$ & $\begin{array}{l}\text { Impact } \\
\text { Output }\end{array}$ & $\begin{array}{l}\text { Policy on } \\
\text { Inflation }\end{array}$ & $\begin{array}{l}\text { Approximate } \\
\text { Sacrifice Ratio }\end{array}$ \\
\hline \multicolumn{5}{|c|}{ A. Group Means } \\
\hline English & 1.1 & -0.45 & -0.21 & -3.1 \\
\hline Scandinavian & 1.8 & -0.52 & -0.22 & -3.7 \\
\hline French & 2.1 & -0.70 & -0.20 & $-4.8^{a}$ \\
\hline German & 2.4 & -1.25 & -0.49 & -5.8 \\
\hline \multicolumn{5}{|c|}{ B. Instrumental Variables Regressions } \\
\hline Coefficient & & -0.46 & 0.05 & -10.4 \\
\hline St. error & & $(0.22)$ & $(0.08)$ & $(10.4)$ \\
\hline
\end{tabular}

a Average excludes Belgium.

Source: Predicted Effectiveness' is from column 5 of Table 5, the 'Impact of Policy' is drawn from columns 2 and 4 of Table 6 . The instrumental variables regression is of columns 2 and 4 of Table 6 on column 5 of Table 5, with columns 2, 3 and 4 of Table 7 as instruments. All of the results in this table use only the eleven countries for which there are estimates in Table 6: Ireland, United Kingdom and United States (English Common Law); Denmark and Sweden (Scandinavian Common Law); Belgium, France, Italy, Portugal and Spain (French Civil Law); and Germany (German Civil Law).

effectiveness and impact of monetary policy from column 4 ("Overall Impact of Monetary Policy") of Table 5 and columns 1 and 3 ("Maximum Impact") of Table 6 . The results follow the pattern predicted by the index of lending channel effectiveness as the impact of policy on output and the approximate sacrifice ratio vary systematically - and as expected - with the origin of a country's legal system.

We can learn a bit more from the data than is recovered from the simple averages reported in the top Panel of Table 8. The question of greatest interest is whether the cross-country heterogeneity in the real effects of monetary policy can be explained by differences in the countries' financial systems, which have their source in the strength of shareholder and creditor rights and the rigor with which these rights are enforced. We can do this without fully accounting for all of the variation in the transmission mechanism if we assume that the La Porta et al. (1997) measures are valid instruments for the financial variables in a simple regression that has the impact of policy on the left-hand side and the overall measure of the lending channel's effectiveness on the right-hand side. That is, I assume that the shareholder, creditor, and enforcement variables are exogenous, while 
the measure of the effectiveness of the lending channel may not be.

The results of these two-stage least squares regressions are reported in Panel B of Table 8. Again, we see that the countries in which the lending channel is expected to be strongest have the biggest sacrifice ratios and show the largest impact of interest rate movements on output. The latter of these relationships has a t-ratio of 2.1 , and so it may even be significantly different from zero. The results for inflation are much less satisfactory: the measures of financial structure appear to be uncorrelated with the impact of policy on prices. Because of the small size of the sample (eleven countries), the estimates are all fairly imprecise, and so I treat them as being only suggestive.

\section{Concluding Remarks}

Among the many challenges facing the new Eurosystem is the possibility that the regions of the euro area will respond differently to interest rate changes. In this essay, I have suggested that differences in financial structure are a proximate cause for these national asymmetries in the monetary policy transmission mechanism. Moreover, I have proposed that these differences in financial structure are likely a result of the EU countries' diverse legal structures. The evidence, although circumstantial, is consistent with this view. Most economists believe that the monetary transmission mechanism will vary systematically across countries with differences in the size, concentration, and health of the banking system, and with differences in the availability of primary capital market financing. The countries of the EU differ quite dramatically in all of the dimensions that would seem to matter, leading to the prediction that the impact of interest rates on output and prices will not be consistent across countries. While the estimates of the impact of interest rate changes on output and inflation tend to be quite imprecise, they do differ, and in the way that is predicted by the state of the countries' financial systems. Finally, we can trace differences in financial structure, the size and scope of capital markets, and the availability of alternatives to bank financing to differences in the countries' legal structures.

What does this mean for the future of financial markets and monetary policy in the euro area? Will the European banking system become more like that of the United 
States? The arguments presented here suggest that unless legal structures are harmonized across Europe, the financial structures will remain diverse, and so will the monetary transmission mechanisms. It will not be enough to make regulatory structures more similar, since such a change will not, in and of itself, alter the structure of capital markets. In other words, I do not view regulatory competition as a force to eliminate the asymmetries in the financial intermediation systems of the EU. ${ }^{20}$ As the European Central Bank (1999) report makes clear, this force has been very weak in the past and is expected to be weak in the future. While we may see cross-border mergers and acquisitions of financial sector firms that take advantage of the expertise of those already doing business in a region, ${ }^{21}$ only a decision to change the existing legal structures so that shareholders and creditors in all EU countries enjoy the same rights will force the movement to a U.S.-style financial structure.

\footnotetext{
${ }^{20}$ It is also extremely unlikely that these difficulties will be overcome by the issuance of debt and equity in a juristiction that offers sufficient investor protections. But unless firms have assets within these juristictions, I do not see this as a solution.

${ }^{21}$ Such developments would be similar to what has happened with the relaxation of interstate branching regulations in the United States, where banks in one state have purchased a bank in another state in order to obtain the legal and regulatory knowledge to do business in that state. Interstate branching has not meant opening new branches of an existing bank in another region.
} 


\section{Data Appendix}

\section{Table 2}

\section{Number of institutions and concentration}

For all countries, concentration is calculated as the assets of the top 5 banks as a percentage of total bank assets.

Austria: Austrian National Bank web page:

http://www.oenb.co.at/stat-monatsheft/tabellen/2001p.htm

Ingesamt, Hauptanstal, for number of institutions;

http://www.oenb.co.at/stat-monatsheft/tabellen/2000_5p.htm

Alle Sektoren, Summe Aktiva(Ohne Rediskonte), for total assets; Austrian National Bank, Economic Analysis Division, for assets of top 5 and top 10 banks.

Belgium: OECD, Bank Profitability: Financial Statements of Banks, 1998, country reports on bank balance sheets, page 36, line \#37 (under supplementary information), for number of institutions; Bank of Belgium, Financial and Economic Statistics Division, for total assets of credit institutions and for share of top 5.

Denmark: OECD, Bank Profitability: Financial Statements of Banks, 1998, country reports on bank balance sheets, page 64, line \#37 (under supplementary information), for number of institutions; Denmark National Bank web page http://www.nationalbanken.dk/nb/nb.nsf/alldocs/F15D9E8CF275ED1A2412565B4003E8BD5, for total assets; IBCA Bankscope database, for assets of top 5.

Finland: Bank of Finland, Financial Statistics Desk, for all figures.

France: Bank of France, Monetary Research and Statistics Division (DESM-SASM) for all figures on credit institutions.

Germany: Deutsche Bundesbank, Monthly Report, May 1998, Table IV.1 (page 16), column 1, for number of institutions; Deutsche Bundesbank, Department of Controlling, Accounting and Organisation, Division C-2, for share of top 5.

Greece: Hellenic Bank Association, The Greek Banking System, April 1998, page 87, for number of institutions, total assets, and assets of top 5 . 
Ireland: Central Bank of Ireland, Monetary Policy and Statistics, for number and total assets of all credit institutions (which include licensed banks, building societies, statesponsored financial institutions, and savings banks). IBCA BankScope database, for assets of top 5 banks.

Italy: Bank of Italy, Research Department, for all figures.

Netherlands: OECD, Bank Profitability: Financial Statements of Banks, 1998, country reports on bank balance sheets, page 192, line \#37 (under supplementary information), for number of institutions; De Nederlandsche Bank, Annual Report, 1997, Tables 1, 2.1, and 2.2, for assets of top 5 banks and for total assets of monetary institutions.

Portugal: Bank of Portugal web page:

http://www.bportugal.pt/publish/frpublish_e.htm

Chart VIII.1 and Table VIII.2, for number of institutions and share of top 5 banks. OECD, Bank Profitability: Financial Statements of Banks, 1998, and country reports on bank balance sheets, page 231, line \#25, for total assets of commercial banks.

Spain: OECD, Bank Profitability: Financial Statements of Banks, 1998, country reports on bank balance sheets, page 236, line \#37 (under supplementary information), for number of banks; Bank of Spain, Statistical Bulletin, June 1998, Tables 61.1 (p. 271), 62.1 (p. 281), 63.1 (p. 291),sum of column 1 in all tables, for total assets of banks, savings banks, and credit co-operatives; IBCA Bankscope database, for assets of top 5 banks.

Sweden: Sveriges Riksbank, Statistical Yearbooks, 1996, Table 6 (page 17), for number of banks; Sveriges Riksbank, Financial Statistics Department, for share of top 5 banks.

United Kingdom: British Bankers Association, Annual Abstract of Banking Statistics, 1997, Table 1.04, for number of institutions; Bank of England, MFSD, for shares of top 5 banks (data relate to all banks and building societies operating in the United Kingdom and so include the business of foreign-owned affiliates in the United Kingdom).

Japan: Bank of Japan, International Department, for all figures for banks and other deposit-taking institutions in Japan, end of fiscal year 1996 (March 1997). 
United States: Federal Financial Institutions Examination Council (FFIEC) Reports of Condition (call reports database), for all figures for commercial banks.

\section{Population}

International Monetary Fund, International Financial Statistics, country report tables, January 1999, line 99z, midyear estimates for all countries.

\section{Table 3}

\section{Number of banks}

Robert N. McCauley and William R. White, "The Euro and European Financial Markets," Bank for International Settlements, Working Papers, No. 41, May 1997, Table 1. FRBNY calculations for Austria, Belgium, Greece, Ireland, Italy, and Portugal, based on ranking of asset size from IBCA BankScope database. In each country, banks were chosen according to 1997 assets. Return on assets, loan loss provisions, net interest margin, and operating cost are drawn from IBCA BankScope database.

\section{Thomson Ratings}

Thomson BankWatch database.

\section{Table 4}

Number of publicly traded firms, market capitalization

International Finance Corporation, Emerging Stock Markets Factbook, 1997, pages 17 and 23 (also available on the Wall Street Journal website: http://update.wsj.com/public/resources/documents/gi-tab5.htm).

\section{Population}

Same as Table 1 .

\section{Privately issued debt}

Bank for International Settlements, International Banking and Financial Market Developments, February 1998, Tables 14 and 15, pages 46-47, amount outstanding, December 1996 figures; sum of figures from Table 14 (international debt securities) and Table 15 (domestic debt securities). 


\section{GDP}

International Monetary Fund, International Financial Statistics, country report tables, January 1999, line \#99b.c for all countries. Year-average exchange rates used for conversion into U.S. dollars (local currency per U.S. dollar, line rf for all countries).

\section{Bank loans}

OECD, Bank Profitability: Financial Statements of Banks, 1998, country reports on bank balance sheets, line \#16 on pages 27, 35, 63, 67, 91, 115, 143, 159, 163, 167, 191, 231, $235,251,259,263,303,307$, and 315 . 


\section{References}

Akerlof, George A., William T. Dickens, and George L. Perry. "The Macroeconomics of Low Inflation." Brookings Papers on Economic Activity (1996:1): 1-59.

Angeloni, Ignazio, and L. Dedola. "From the ERM to the Euro: A Soft Transition?" Working paper, Banca d'Italia, June 1998.

Bernanke, Ben S. "Nonmonetary Effects of the Financial Crisis in the Propagation of the Great Depression." American Economic Review 73 (June 1983): 257-76.

"Credit in the Macroeconomy." Federal Reserve Bank of New York Quarterly Review (spring 1993): 50-70.

Bernanke, Ben S., and Alan S. Blinder. "The Federal Funds Rate and the Channels of Monetary Transmission." American Economics Review 82 (September 1992): 901-21.

Bernanke, Ben S., and Mark Gertler. "Agency Cost, Net Worth and Business Fluctuations." American Economic Review 79 (March 1989): 14-31.

- "Financial Fragility and Economic Performance." Quarterly Journal of Economics 105 (February 1990): 87-114.

Calvo, Guillermo A. "Staggered Price Setting in a Utility-Maximizing Framework." Journal of Monetary Economics 12 (September 1983): 383-98.

Cecchetti, Stephen G. "Distinguishing Theories of the Monetary Transmission Mechanism." Federal Reserve Bank of St. Louis Economic Review 77 (May/June 1995): $83-97$.

."Practical Issues in Monetary Policy Targeting." Federal Reserve Bank of Cleveland Economic Review 32 (1996 Quarter 1): 2-15.

. "Policy Rules and Targets: Framing the Central Banker's Problem." Federal Reserve Bank of New York Economic Policy Review 4 (June 1998): 1-14.

Cecchetti, Stephen G., Margaret Mary McConnell, and Gabriel Perez Quiros. "Policymakers' Revealed Preferences and the Output-Inflation Variability Trade-off." Unpublished paper, Federal Reserve Bank of New York, February 1999.

Cecchetti, Stephen G., and Robert W. Rich, "International Evidence on the Sacrifice Ratio: Do We Know How Big It Is?" Unpublished paper, Federal Reserve Bank of New York, February 1999.

Christiano, Lawrence J., Martin Eichenbaum, and Charles L. Evans. "Sticky Price and Limited Participation Models of Money: A Comparison." European Economic Review 41 (June 1997): 1201-49.

Danthine, Jean-Pierre, Grancesco Giavazzi, Xavier Vives, and Ernst-Ludwig von Thadden. The Future of European Banking. London: Centre for Economic Policy Research, 1999. 
de Bondt, G.J. "Monetary Transmission in Six EU-Countries: An Introduction and Overview." Research Memorandum no. 527, De Nederlandsche Bank, 1997.

Dornbusch, Rudiger, Carlo Favero, and Franceso Giavazzi. "Immediate Challenges for the European Central Bank." Economic Policy 28 (April 1998): 17-64.

Ehrmann, Michael. "Will EMU Generate Asymmetry? Comparing Monetary Policy Transmission Across European Countries." European University Institute Working Paper no. 98/28, October 1998.

European Central Bank. Possible Effects of EMU on the EU Banking Systems in the Medium and Long Term. Frankfurt, Germany: European Central Bank, February 1999.

Feldstein, Martin. "The Costs and Benefits of Going from Low Inflation to Price Stability." In C. Romer and D. Romer, eds., Reducing Inflation, 123-66. Chicago: University of Chicago Press, 1996.

Feldstein, Martin, ed. The Costs and Benefits of Achieving Price Stability. Chicago: University of Chicago Press for NBER, 1999.

Fischer, Stanley. "Long-Term Contracts, Rational Expectations, and the Optimal Money Supply Rule." Journal of Political Economy 85 (April 1977): 191-205

Gerlach, Stefan, and Frank Smets. "The Monetary Transmission Mechanism: Evidence from the G-7 Countries." CEPR Working Paper no. 1219, July 1995.

Gertler, Mark, and Simon Gilchrist. "The Role of Credit Market Imperfections in the Monetary Transmission Mechanism: Arguments and Evidence." Scandinavian Journal of Economics 95 (1993): 43-64.

Grandy, Christopher. "New Jersey Corporate Chartermongering, 1875-1929." Journal of Economic History 49 (September 1989): 677-92.

Groshen, Erica, and Mark Schweitzer. "Identifying Inflation's Grease and Sand Effects in the Labor Market." NBER Working Paper no. 6061, June 1997.

Hubbard, R. Glenn. "Is There A 'Credit Channel' of Monetary Policy?" Federal Reserve Bank of St. Louis Economic Review 77 (May/June 1995).

Kashyap, Anil K, and Jeremy C. Stein. "The Role of Banks in monetary Policy: A survey with Implications for the European Monetary Union." Federal Reserve Bank of Chicago Economic Perspectives (September/October 1997): 2-18.

"Monetary Policy and Bank Lending." In N. Gregory Mankiw, ed., Monetary Policy. Chicago: University of Chicago Press for NBER, 1994.

Kieler, Mads, and Tuomas Saarenheimo. "Differences in Monetary Policy Transmission? A Case Not Closed." Unpublished paper, European Commission, Directorate General II - Economic and Financial Affairs, May 1998.

King, Robert G., Charles I. Plosser, James H. Stock, and Mark W. Watson. "Stochastic Trends and Economic Fluctuations." American Economic Review 81 (June 1991): 819-40. 
La Porta, Rafael, Florencio Lopez-de-Silanes, Andrei Shleifer, and Robert W. Vishny. "Legal Determinants of External Finance." Journal of Finance 52 (July 1997): 113150 . 55.

McCauley, Robert N., and William R. White. "The Euro and European Financial Markets." Bank for International Settlements Working Paper no. 41, May 1997.

Rotemberg, Julio J. "A Monetary Equilibrium Model with Transactions Costs." Journal of Political Economy 92 (February 1984): 40-58.

Taylor, John B. "Aggregate Dynamics and Staggered Contracts." Journal of Political Economy 88 (February 1980): 1-23.

Vlaar, Peter J.G., and Helene Schuberth. "Monetary Transmission and Controllability of Money in Europe: A Structural Vector Error Correction Approach." Unpublished paper, De Nederlansche Bank, May 1998.

White, William R. "The Coming Transformation of Continental Banking?" Bank for International Settlements Working Paper no. 54, June 1998. 